\title{
Torn Between Two Worlds: Hybridity and In-between Identity Recognition in Goli Taraqqi's Two Worlds
}

\author{
Nasser Najafi Shabankare \\ English Language Department \\ Islamic Azad University, Firozabad Branch \\ E-mail:Nasser.najafi@yahoo.com \\ Bahar Mehrabi (Corresponding author) \\ PhD Candidate, English Literature \\ Department of English and Foreign Languages \\ Shiraz University, Shiraz, Iran \\ E-mail: baharmehrabi22@gmail.com
}

Doi:10.7575/aiac.alls.v.5n.5p.119

Received: 11/07/2014

URL: http://dx.doi.org/10.7575/aiac.alls.v.5n.5p.119

Accepted: 31/08/2014

\begin{abstract}
As one of the contemporary Iranian women writers living in the U.S, Goli Taraqqi's fiction is mostly concerned with pains and difficulties of migrant Iranian women in other countries. Bearing a biographical resemblance, her sequence collection to Scattered Memories, entitled Two Worlds retells interrelated short stories of a woman writer narrator, entangled in an asylum in Paris, who digs into her past, writes stories about it, and is able to regain her sanity in the end, as she gets ready to enter the brave new world. The process of identity recognition is to be approached with an eye on Homi K, Bhabha's assertions about 'hybridity' and 'in-between' as explained in his 1994 Location and Culture, to see to what degree the newly gained identity, which is resembled to a resurrection, is in fact a hybrid one.
\end{abstract}

Keywords: Goli Taraqqi, Two Worlds, Homi , K Bhabha, Hybridity

\section{Introduction}

As a subcategory in the area of post-colonial studies, diaspora literature covers a vast number of narratives, both in fiction and visual form, which would encompass the stories of migration and identity gaining and its several facets. Cotemporary Iranian literature is doomed to accept the so-called literature of diaspora as an inevitable part. It was specifically after Iranian Revolution of 1979 that a wave of migration started to move to different parts of universe.

Migrant writers could be divided into two groups of first and second generation of authors. The first group would naturally be the ones who have been living in Iran, but have left the country. Nonetheless, in contrast to the second generation of writers who were born there, the first generation carried memories of motherland in their luggage. Nostalgia and displacement difficulties would then appear every now and then in their writings.

Goli Taraqqi, Iranian contemporary female writer, is currently living in the U.S, while most of her stories are written in Persian and happening in Iran. She is considered as a writer of diaspora literature who writes generally about the pains and difficulties faced by Iranian migrants overseas. Bearing a biographical tone, most of her stories demonstrate an Iranian woman living abroad and all the various stages she goes through to gain her new identity in the new world. As such her stories have the potentiality to be approached from the view of one of the most prominent thinkers in area of post-colonial and diaspora literature studies, Homi, K Bhabha, to feature certain properties of identity in her stories. Two Worlds is a collection of her short stories chosen here to be approached from the views of Homi Bhabha.

\section{Discussion}

\section{2-1Homi Bhabha}

As a leading prominent figure in post-colonial studies, Bhabha is himself under the influence of post-structuralist theorists such as Derrida, Lacan and Foucault. The terms 'mimicry' and 'hybridity' are employed by him to argue that cultural production is a very ambivalent and multifaceted concept. As he says: " These strategies of mimicry, hybridity, incommensurability of translation, which I've been variously trying to interpret, are, I think, the unspoken, unexplored moments of history of modernity" (location 67).

In his 1994 book entitled The Location of Culture, he draws the concept of 'ambivalence' from psychology to be adapted to the colonial discourse theory. The concept is used to describe the complex web of relationship between the colonizer and the colonized, characterized by a series of attraction and repulsion action. Ambivalence acts in the contrary direction with the authority of colonial domination. While colonial discourse is after producing "compliant subjects who reproduce its assumptions, habits and values-that is, 'mimic' the colonizer," the result is "ambivanlent subjects whose mimicry is never far away from mockery" ( Ashcroft, Griffithd, 1999, 12-13). As such, ambivalent would not be very much pleasing aspect of the colonial discourse for the colonizer. This is a property of colonialism which would ultimately lead to its own destruction. "In reality any simple binary opposition between the colonizers and the colonized or between races is undercut by the fact that there are enormous cultural and racial differences within each of these categories as well as cross-overs" (Loomba 1998 105). 
Borrowing Edward Said's notion of mimeses and its significance for the authority gaining of the colonizer, Bhabha asserts that the colonial mimicry is the tool at hands of colonial power through which it is able to impose its authority through "strategies of individuation and domination." through 'dividing practices' that differentiate "us from "them" while covering over internal contradictions. According to Bhabha Colonial mimicry is the desire for a reformed, recognizable Other, as a subject of a difference that is almost the same, but not quite, which is to say, that the discourse of mimicry is constructed around an ambivalence; in order to be effective, mimicry must continually produce its slippage, its excess, its difference. (Location 126)

As it comes from these words, the very act of mimicry is doomed to a final production of a 'blurred copy' of the colonizer. In fact, adaptation of the colonized habits and assumptions as well as their values is done through a number of inevitable inaccuracies and inconsistencies which would give the native a chance to be uniquely different and selfidentified. In such way, Bhabha asserts a sort of 'menace' and 'mockery' in the process of imitation. The menace is the result of the colonized 'double vision' which in disclosing the ambivalent of colonial discourse also disrupts its authority" (Location 88). Benita Parry (1987) defines the mimic man as "a contradictory figure who simultaneously reinforces colonial authority and disturbs it" (42).

Bhabha's concepts define suitable framework for approaching the literary works of art which have been produced in countries other than the homeland of the writer. Daphne Grace (2007) clarifies the relationship between the postcolonial literature and Diasporic literature as follows:

postcolonial studies involve an examination of how

individuals or groups negotiate and overcome situations of domination

and subordination - often a struggle expressed in terms of ways of

being and becoming, of finding fulfilment, freedom and agency. It

also analysed ways in which colonized peoples rewrote and reclaimed

their own individual and national identity, and their strategies for

writing in the face of their categorisation of otherness. (14)

Diaspora literature would then yield into such view. The diaspora writer is like the colonized person, whose identity and individuality as well as his collective senses are being under constant attack of the colonizers, or the host countries. Although as Kral (2009) suggests: the theoretical innovations of Edward Said, Homi Bhabha, Gayatri Spivak, Stuart Hall, Paul Gilroy, James Clifford" belong to the first generation of the theoricians of diaspora literature whose basic theme is that of nostalgia for the homeland and the displacement consequences", (13) Bhabha's ideas would be applicable to the writers of the first generation of the diaspora writers, since they are still entangled in the web of past and their background, trying to adapt where they come from to where they are finding themselves. In this journey, the migrant is akin a colonized one who is being colonized culturally in another land, far away from his homeland. Thought the nostalgic feelings and all the displacement challenges are to be faced and eventually overcome if the life is going to flow on, the very underlying 'menace' would always skip notice as Bhabha asserts.

Assuredly the mimicry process is also gone through by the migrant who is seeking a new identity to get accepted in new home, while the menace and mockery are working hand in hand to contribute to the web of ambivalence so much so that the original identity of the migrant is dissolved in the process, while at some points he must still feel that, ironically enough, he is still linked to the past and it is through such still connections with the homeland that he is able to maintain his own homeland identity while also acquiring a new one. Counting on Bhabha's and Hall's assertions about the hybrid identity gained in diaspora, Daphne Grace (2007) affirms the identity would always bear something from the rubrics of the past: "the diasporic experience is a diverse and self-contradictory one involving movement, travel and a reestablishment of "home"; fragmentation and a desire for wholeness; elitism and shifting categorisation of class; a release from but simultaneously a jealous guarding of tradition" (21).

\subsection{Taraqqi's Hybridity}

The process is the one Goli Taraqqi, the Iranian diasporia woman writer, born in Tehran and living in the U.S goes through in her Two Worlds. Mirabedini (2004) categorizes the stories of Taraqqi to belong to the lable of "Migration literature" (1403). Having lived in France for almost 25 years makes her a very prominent writer of diaspora literature in the eye of all articles present in Ali (2004) review of her works entitled. Goli Taraghi: Criticism and Analysis of the Works.

Migration in Iran has a very long history. It was especially after the Ghajar era when Iranians, like other Asian and Middle-Eastern nations, became widely familiar with the ease of life provided for them in West. The image of a life much more comfortable was tempting enough to make lots of people move to other countries. However, the Eastern migrant would not only had to face the economic and political challenges, but also he had another crisis to go through that $\mathrm{f}$ identity. Such process of cultural adaptability which the migrants go through is a bilateral blade which would either lead to compatibility or to the longing for the past and the feeling of nostalgia which still lingers in their mind. Women are especially under double pressure. Thus, women writers who have had the experience of migration would best give a minute picture of the pressure and difficulties women go through in their migration.

Vatanabadi and Khorammi (2004) in their comprehensive study about the stories of migration writers rightly state that: "Such a mode did not take shape until the massive migration of Iranians after the 1979 Revolution". Though a generation before, were writers who had mainly had the experience of living abroad, for their education or living 
permanently, the generation of writers over the "past few years" have been migrating more to different parts of the continent. (vii)

Two Worlds (Do-donya) is a sequence to the previous collection of short-stories Scattered Memories or (Khaterat-eparakande) which as the writer claims in the preface, is written so as to complete the previous project. " Three stories of 'Shemiran Bus (Otobus-e Shemiran) Grandmas' House (Khaneye Madarbozorg) and 'Little Friend' (Doste Kochak) all belong to this collection, and the story of Father was incomplete which is now re-written) ( Preface). It was first published in 2002 by Nilofar publications in Iran, though written in the U.S and the collection contains seven interrelated short stories which are being told, in a met fictional manner, in the presence of the author. "The First Day" is the first story of the collection, which is the focus of attention here, since it retells the story of how the writer is able to overcome the difficulties she is facing as she is hospitalized apparently in an asylum in Paris.

The setting is "August 1988, Weel Dowry Asylem, Paris. The reader is invited to travel back with the narrator to her previous life in Iran, Tehran, essentially her childhood. The first part of the flashback is haunted by the overruling image of a father, which is reminiscent of the patriarchal system of Iranian families of the time. "I see my father's grand shadow, stretched far along the end of Shemiran Garden" (Taraqqi 11)

The father is pictured as an inseparable part of the past memories which continue to haunt the narrator all throughout the rest of the novel, so much so that the whole other stories are shaped as the memories of the past are brought into life by her revitalized imagination. She has had a dream of her father in which he is in one of "...ancient Egypt cities.....He was looking ahead...probably to his children's destiny, to the ruins of Shemiran Garden, to his scattered tribe all around the world, and to me, the one prisoned among all these strangers" (12)

As the story moves on, the residents of the asylum, from the lady Dr who supervises her behavior, to the old lady who tries to comb her hair whenever they meet, or the people all around the 'forced' lunch table, which she has to unwillingly attend, prove to provide an environment for her which intensifies the experience of living in another land. She is constantly entangled with this question that "What am I doing here". The asylum thus, could be regarded as a macrocosm for the strange residence in which she is going to live on, though there is no direct notification of the "colonialist Westerner" as it is evident in the very first lines of another story by her called 'The Wolf Lady' which traces the identity formation process of a woman living in France with her two children. "A belief that if we are in this miserable state and nothing remains of our vain glory and grandiloquence, you are to blame; you, the materialist, money-loving, colonialist Westerner"( Taraqqi, 2004, 130-144)

Counting on the first story as the one in which the other stories are shaped and written, would necessitate the significance of the asylum as a place in which the colonial discourse is at work which forms the relationships among the residents and the narrator, as well as how the memories come to assist the narrator gain, rather than regain, her identity which is a hybrid of the new and old one. In "Signs Taken for Wonders," Bhabha describes hybridity as "a partial and double force that is more than the mimetic but less than the symbolic, that disturbs the visibility of the colonial presence and makes the recognition of its authority problematic', (173).

The presence of Lady Dr, as the only representative of an authority in the story is the symbol of a colonizer in the destination country who is there to change the identity of the colonized, in this case the woman writer, in such a way that her presence is blurred and is not sensed very much throughout the story. However, her role is quite crucial as she triggers the process of writing for mental healing of the narrator. In the process, though apparently a happy ending is reached through as she moves to solemnity and is able to leave the asylum, wha she has gained is a hybrid 'in-between' identity which is shaped basically through her regained affinity with past memories of the homeland, also a new one shaped under the discourse of Lady Dr who is able to 'heal' in the hidden way that she would comfort with the outside new world, though it skips notice.

The hybridity seems to be neglected by the narrator as she seems to be able to move out of the asylum and look for her new life with her children. "The Last Day" is the last story of the collection which in contrast to the beginning day is devoted to the apparent sage and health of mind as acquired by the narrator through the process of writing.

In the "First Day" the story teller recalls lady Dr encouraging her all the time to write whatever comes to her mind. "Lady Dr is aware of my love for writing and has given me a paper and pen to write...I sit down but I do not know where to begin or what to write.." (Taraqqi 23) It is through writing, especially of her memoirs in Tehran, which she is able to overcome the scattered undisciplined thoughts and voices she hears in her mind, and put herself up together once more. However, the point is she is, in Bhabha's terms, mimicking the ideologies of the colonized, in this case that of writing, though it is of her memories past in the homeland. Thus, she is actually in an ambivanlant way, trying to adapt herself to the new environment, so that she could enter the new society.

The narrator remains a rather detached observer all throughout the stories. Though she is present in all of them, the main characters are the ones which belong back to her childhood and now to her teenager years in Tehran at the time of Coup D'état in 1953, especially in 'Shiraz Flowers' and other stories. Digging into the past seems to make her pass through the stages of nostalgia and displacement and she is apparently able to find a place for herself in diaspora, or at least start off the journey. Bhabha (1994) counts a danger for clinging into past and histories in the process of identity formation. He asserts that "fixity and fetishism of identities" are the ultimate results of adhering to past memories, which would result the formation of a 'hybrid' identity. (14).

Past memoirs are present all throughout Tarraghi's Two Worlds, these are the memories which would eventually lead to her final survival. Zarlaki (2010) pinpoints this nostalgic aspect of Taraqqi's works "Goli Taraghi has not returned and is pleased with that untouched world of memories....her hear lives in memories, and she writes of past and of motherland. This is the nostalgic nature of Taraghi's stories" (112). 
Nostolgia and all displacement challenges are seemingly buried in the 'Last Day". The opening lines of the story go like this: "I manage to finish the story of 'Father' with all the difficulties while struggling with pain and harshness. I write the last word. I put the last full stop and close the door to past" (Tarraghi, 2002 207). She then moves on to justify the necessity of calling out the past, and moving back to every minute detail so that she would be able to complete the last puzzle of her soul (ibid). The narrator expresses her extreme joy and happiness for getting back to life again. Past is gone and present is here to be lived on. "I know that this pleasing joy is temporary.....For Now I am conscious and light and I stick to this unlimited time of 'now'..."(Taraqqi 2004, 207) (my italics)

'They" are the ones who allow her to use the phone, change her room and make a contact to 'whomever' she wants. This newly defined 'hybrid' identity, is a mingling of past and present. Past is still there, her children are from homeland and she is still carrying her story book with herself. However, she expresses the new identity as a new life. The process is being akin to a resurrection of both the soul and the body. All throughout the next three pages, she explains the feelings and enthusiasm she feels to be coming to her as she is to experience a whole brave new world. Past has acted as a bridge for her, by passing through which she has been able to step into the Island. What escapes her notice is the fact that the colonizers at the asylum have actually built the new identity and the world for her. She is actually not reborn in the sense a newly born child, but, rather is stepping 'in-between' as a 'hybrid' 'trans-national' woman from Iran, who is able to cope with the new world now.

\section{Conclusion}

Taraqqi's writings are considered to belong to the category of literature of diaspora as the dominant theme of most of her short stories is nostalgia. The displacement and all the difficulties the new comers, mostly women, encounter as they enter brave new world is the dominant motif in most of her short stories. The collections of her short stories are usually separated from one another, still linked together in one way or another so that as she states they could be considered as parts of a novel. (Taraqqi2002, Preface)

The omnipresent narrator in her sequence collection to Scattered Memories, entitled Two Worlds, bears essential resemblance to Taraqqi herself. She is a middle eastern woman from Iran, who has now ended up in an asylum in France and is entangled with her identity. Torn between past and present, she is struggling to be born anew and get accepted to the new society. Besides the studies which have so far been concerned with the properties of literature of diaspora in Taraqqi's fiction, the present article aimed at investigating this newly gained identity on the basis of Homi Bhabha's theories. Bhabha asserts that through a process of mimicry, the colonized gains habits, values and cultural assumptions of the colonizers, a path which is accompanied by mockery as well. The final identity gained is not an absolutely new one, but rather a hybrid identity, which puts the person 'in-between'. The past is still present, though it seems a new entity is born.

Taraqqi's narrator is so much entangled with various senses of nostalgia and displacement that she starts writing as a means to help her recollect her conscious and unconscious memories. The asylum proves to act a macrocosm for the new world. Lady Dr 's act in encouraging her to pursue her writings, functions as a colonizers attempt to dominate her thinking. Though apparently she is writing about her past memories, the very act of writing is a psychological step in the process of achieving her identity. What she is doing is actually mimicking the ideology of the colonizer, trying to adapt her to the new environment. The ultimate result proves this, as she has gained a seemingly new identity, which proved to be, in Bhabha's terms, a 'hybrid' identity which places her somewhere 'in-between'.

\section{References}

Ashcroft, Bill, Gareth Griffiths, and Helen Tiffin (1999) . Key Concepts in Post-Colonial Studies. London: Routledge.

Bhabha, Homi, K. (1994) The Location of Culture. London and NewYork: Routledge

---. "Signs Taken for Wonders: Questions of Ambivalence and Authority under aTree outside Delhi, May 1817. In

“Race,” Writing and Difference. Ed. Henry Louis Gates, Jr. Chicago: University of Chicago Press, 1986. 163-84.

Dehbashi, A. (2004). Goli Taraghi: Criticism and Analysis of the Works. Tehran:Ghatreh.

Grace, Daphne (2007). Relocating Consciousness, Diasporic Writers and the Dynamics of Literary Experience. NewYork, Radopi,.

Kral, Franscious (2009) Critical Identities in Contemporary Anglo-phone Diaspora Literature. Palgrave.

Loomba, Ania. (1998) Colonialism/Postcolonialism. New York: Routledge.

Mirabedini, H. (2004). Sad Sal Dastan Nevisi-e-Irani (One Hundred Years of Story

Writing in Iran). Tehran: Cheshme.

Parry, Benita. (1987)"Problems in Current Theories of Colonial Discourse." Oxford Literary Review 9 (27-58).

Taraqqi (2004) The Wolf Lady. Translated by Vatan Abadi and Khorami, Another Sea, Another Shore, Persian Stories of Migration. Interlink Work Fiction (130-144)

Taraghi, G. (2002). Two Worlds. Tehran: Niloofar.

Vatan Abadi, Shouleh \& Khorrami, Mohammad Mehdi (eds) (2004). Another Sea, Another Shore, Persian Stories of Migration. Interlink Work Fiction

Zarlaki, Sh. (2010). Khalse-ye-Khaterat. Tehran: Niloofar. 